\title{
Alostonia scholaries Foliar Galls, A Disease or Pollution Indicator
}

\section{Taswar Ahsan*}

Shenyang Agricultural University Shenyang, China

*Corresponding Author: Taswar Ahsan, Shenyang Agricultural University Shenyang, China.

Received: October 16, 2019; Published: October 28, 2019

DOI: 10.31080/ASAG.2019.03.0696

\begin{abstract}
There are two opinion about foliar galls of Alostonia scholaries. Pollution indicator or induced by the insects. Both points are opposite to each other. If we consider it induced by insects, then there is a possibility the insects act as vector to transmit the virus. There should be a research carried to determine the presence of virus.
\end{abstract}

Keywords: Alostonia scholaries; Pollution Indicator; Virus

\section{Introduction}

Alostonia scholaries belongs to family Apocynaceae and one of the graceful ornamental plants [1,2]. Besides the medicinal applications, it's easy to grow as ornamental plant, even in polluted regions. A. scholaris also a biological indicator and can grow in drought conditions $[1,3]$.

Alostonia scholaries foliar galls as pollution indicator

Recently observed, galls were appeared on the foliar part of A. scholaris by the pollution or induced by the pollution [4].

\section{Alostonia scholaries foliar galls induced by insect}

According to the researcher foliar galls induced the Pauropsylla tuberculata crawf [4]. Several studies carried out on foliar galls morphology, anatomy and biochemistry after insect (Pauropsylla tuberculata) infection and deposition their eggs $[4,5]$.

Virus vector

The majority of plant-infecting viruses are transmitted to their host plants by vectors [6]. Transmission from host to host is a crucial step in the life cycle of pathogens, particularly of viruses, ensuring spread and maintenance in host populations. The immobile nature of plants and the strong pectin and cellulose barrier surrounding cells have constrained most plant virus species to use vectors (mainly insects) for exit, transfer and entry from one host to another. Circulative viruses, by definition, enter the insect body and disseminate to various tissue systems prior to their transmission to plant hosts. Circulative viruses include both those that disseminate but do not replicate in the body of the insect (non-propagative) and those that replicate (propagative) in different tissues. The precise route of dissemination from point of entry.

\section{Conclusion}

Much like the family Potyviridae, the virus genera in the family Geminiviridae are transmitted by vectors in a virus genus-specific manner. For example, whiteflies transmit viruses in the genus Begomovirus, e.g., Tomato yellow leaf curl virus (TYLCV), while leafhopper vectors transmit viruses in the genus Mastrevirus, e.g., Maize streak virus (MSV). Like luteovirids, the route of the Begomovirus begins with the insect feeding on phloem sap of infected plants and virions are ingested and travel through the alimentary canal (reviewed in [7]). Both points are opposite to each other. If we consider it induced by insects, then there is a possibility the insects act as vector to transmit the virus. There should be a research carried to determine the presence of virus [8].

\section{Conflict of Interest}

There is no conflict of interest.

\section{Ethical Approval}

No data was used in this article which needs approval. 


\section{Bibliography}

1. Muhammad S., et al. "Alstonia scholaris (1.) r. br.-planted bioindicator along different road-sides of lahore city". Pakistan Journal of Botany 46 (2013): 869-873.

2. Saini D and Sarin R. "SDS-PAGE analysis of leaf galls of Alstonia scholaris (L.) R". British Journal of Plant Pathology and Microbiology 3 (2012): 121.

3. Biswas SM., et al. "Foliar gall and antioxidant enzyme responses in Alstonia scholaris, R. Br. After psylloid herbivory-an experimental and statistical analysis". Global Journal of Botanical Science 2 (2014): 12-20.

4. Talukdar P., et al. "Galls on Alstonia scholaris leaves as air pollution indicator". World Scientific News 52 (2016): 181-194.

5. Albert S., et al. "Morphological, anatomical and biochemical studies on the foliar galls of Alstonia scholaris (Apocynaceae)". Brazilian Journal of Botany 34 (2011): 343-358.

6. Whitfield AE., et al. "Insect vector-mediated transmission of plant viruses". Virology 479 (2015): 278-289.

7. Gray S., et al. "Circulative,"nonpropagative" virus transmission: an orchestra of virus-, insect-, and plant-derived instruments". Advances in Virus Research 89 (2014): 141-199.

8. Gutiérrez S., et al. "Plant feeding by insect vectors can affect life cycle, population genetics and evolution of plant viruses". Functional Ecology 27 (2013): 610-622.

Volume 3 Issue 11 November 2019

(C) All rights are reserved by Taswar Ahsan. 